\title{
INTEGRASI NILAI-NILAI KARAKTER BANGSA PADA KEGIATAN PEMBELAJARAN
}

\author{
Anik Ghufron \\ FIP Universitas Negeri Yogyakarta (e-mail: anikghufron@uny.ac.id)
}

\begin{abstract}
The Integration of the Nation's Character Values into Intructional Activities. One of the crucial problems in the national education system is the moral problem. There is evidence that indicates a moral crisis among students. This shows that educational institutions fail to prepare graduates with good morality. To solve this problem, the nation's character values need to be integrated in the implementation of the formal curriculum. By doing so, teachers can help students to actualize each learning domain through the competency formulation and the students can simultaneously carry out relevant moral actions. Integrating the nation's character values into the curriculum can be done in three stages: introduction, implementation, and evaluation. Each stage can improve students' good characters based on the formulation of the competency standard. Such an integration has implications for schools, teachers, parents, and students.
\end{abstract}

Keywords: integration, nation's character values, instructional activities

\section{PENDAHULUAN}

Salah satu persoalan krusial bangsa Indonesia, terutama yang berkaitan dengan penyiapan SDM siap kompetisi di era global adalah krisis nilai-nilai karakter bangsa. Pada saat ini, bangsa Indonesia sedang mengalami krisis nilainilai karakter bangsa, yang ditandai dengan semakin maraknya kejahatan dan tindakan-tindakan lain yang tidak mencerminkan nilai-nilai karakter bangsa, yang dilakukan oleh orang-orang berpendidikan dan ada yang punya jabatan strategis di pemerintah atau masyarakat. Kita tidak bisa lagi menghitung dengan jari berapa mantan pejabat pemerintah yang dihukum karena keterlibatannya dalam perkara kriminal, korupsi, dan penyalahgunaan jabatan.
Persoalan di atas juga terjadi di lingkungan persekolah. Misalnya, kebocoran soal ujian nasional terjadi di Medan, Bandung, dan Solo (Kompas, 26 Maret 2010). Realita ini menunjukkan bahwa institusi pendidikan belum berhasil menyiapkan lulusan yang memiliki komitmen dan bermoral tinggi. Dalam konteks ini, Doni Koesoema (Kompas, 26 April 2007) menengarai bahwa pendidikankitasedang menyimpan bom waktu yang akan menghancurkan sendisendi tatanan sosial kapan saja. Sementara itu, agar bisa memenangi kompetisi di berbagai bidang kehidupan mensyaratkan tersedianya SDM cerdas, cendikia, dan bermoral.

Apa yang dapat diperbuat bangsa Indonesia, khususnya para civitas aka- 
demika LPTK untuk memecahkan masalah atau krisis nilai-nilai karakter bangsa yang melanda bangsa Indonesia? Salah satu cara yang bisa dilakukan adalah mengintegrasikan nilai-nilai karakter bangsa ke dalam kurikulum sekolah. Cara ini dipandang relevan digunakan karena setiap mata pelajaran akan termuati nilai-nilai karakter bangsa secara spesifik dan kontekstual. Alasan lainnya, karena pengembangan nilai-nilai karakter bangsa tidak secara khusus diberikan pada mata pelajaran tertentu dalam kurikulum sekolah. Dengan cara demikian, sekolah diasumsikan mampu menyiapkan SDM kompeten di bidangnya dan sekaligus peserta didik memiliki nilai-nilai karakter bangsa sebagaimana yang telah digali dan disepakati pendahulu kita dan tetap masih relevan dalam kehidupan seharihari pada saat ini.

Tulisan ini memuat tiga hal esensial. Pertama, makna nilai-nilai karakter bangsa. Kedua, pola integrasi nilai-nilai karakter bangsa pada kegiatan pembelajaran di sekolah. Ketiga, implikasi bagi sekolah, guru, peserta didik, dan orang tua.

\section{MAKNA NILAI-NILAI KARAKTER BANGSA}

Diskusi tentang nilai-nilai karakter bangsa, terlebih dahulu kita perlu memahami makna karakter. Bertitik tolak dari pemahaman karakter, kemudian dikemukakan nilai-nilai yang terkandung dalam makna karakter tersebut. Selanjutnya, nilai-nilai karakter tersebut akan diintegrasikan ke dalam kegiatan pembelajaran pada setiap mata pelajaran yang tertera di kurikulum sekolah.
Apa yang dimaksud dengan karakter? Karakter berarti tabiat atau kepribadian. Hill (Wanda Chrisiana, 2005) mengatakan, "Character determines someone's private thoughts and someone's action done. Good character is the inward motivation to do what is right, according to the highest standard of behavior in every situation". Dalam konteks ini, karakter dapat diartikan sebagai identitas diri seseorang.

Menurut Ekowarni (2010), pada tatanan mikro, karakter diartikan; (a) kualitas dan kuantitas reaksi terhadap diri sendiri, orang lain, maupun situasi tertentu; atau (b) watak, akhlak, ciri psikologis. Ciri-ciri psikologis yang dimiliki individu pada lingkup pribadi, secara evolutif akan berkembang menjadi ciri kelompok dan lebih luas lagi menjadi ciri sosial. Ciri psikologis individu akan memberi warna dan corak identitas kelompok dan pada tatanan makro akan menjadi ciri psikologis atau karakter suatu bangsa. Pembentukan karakter suatu bangsa berproses secara dinamis sebagai suatu fenomena sosio-ekologis.

Berdasarkan pengertian di atas, dapat dikatakan bahwa karakter merupakan jati diri, kepribadian, dan watak yang melekat pada diri seseorang. Karakter selalu berkaitan dengan dimensi fisik dan psikis individu. Karakter bersifat kontektual dan kultural.

Karakter bangsa merupakan jati diri bangsa yang merupakan kumulasi dari karakter-karakter warga masyarakat suatu bangsa. Hal ini sesuai dengan pendapat Endang Ekowarni (2010) bahwa karakter merupakan nilai dasar prilaku yang menjadi acuan tata nilai interaksi antar manusia (when character 
is lost then everyting is lost). Secara universal berbagai karakter dirumuskan sebagai nilai hidup bersama berdasarkan atas pilar: kedamaian (peace), menghargai (respect), kerjasama (cooperation), kebebasan(freedom), kebahagiaan (happinnes), kejujuran (honesty), kerendahan hati (humility), kasih sayang (love), tanggung jawab (responsibility), kesederhanaan (simplicty), toleransi (tolerance) dan persatuan (unity).

Dengan batasan yang demikian, para pengambil kebijakan atau pihak-pihak penyelenggara pendidikan perlu memperhatikan dan mengetahui makna karakter dan karakter bangsa. Hal ini perlu dilakukan karena kesalahan atau perbedaan makna tentang karakter dan karakter bangsa berpengaruh terhadap ketercapaian tujuan pendidikan nasional yang memuat nilai-nilai karakter bangsa.

Nilai-nilai apa saja yang terkandung di dalam karakter bangsa? Berdasarkan makna karakter bangsa yang dipaparkan di atas, nilai-nilai yang terkandung di dalamnya adalah nilai-nilai yang berkembang, berlaku, diakui, diyakini, dan disepakati untuk dilaksanakan oleh setiap warga masyarakat atau negara. Nilai-nilai tersebut, menurut Ekowarni (2010) tidak lain adalah nilai-nilai luhur (supreme values) yang merupakan pedoman hidup (guiding principles) yang digunakan untuk mencapai derajat kemanusiaan yang lebih tinggi, hidup yang lebih bermanfaat, kedamaian dan kebahagiaan.

Kemanusiaan yang dimaksud adalah umanitarianisma (perikemanusiaan) yang meliputi; solidaritas sesama manusia, menghormati hakekat dan mar- tabat manusia, kesetaraan dan tolong menolong antar manusia, menghormati perbedaan dalam berbagai dimensi antarmanusia, menciptakan kedamaian. Budi pekerti sebagai nilai luhur adalah pilihan perilaku yang dibangun berdasarkan atas nilai-nilai yang diyakini sehingga sering diposisikan sebagai nilai instrumental atau cara mencapai sesuatu atau sikap terhadap sesuatu. Dengan budi pekerti, kita akan berbakti, mengabdi dengan sepenuh jiwa raga kepada bangsa dan kita bukan bangsa pencaci ataupun penghujat.

Ekowati (2010) juga mengatakan bahwa bangsa Indonesia yang bersifat multi etnis memiliki khasanah ajaran, wewarah, tuntunan yang sangat kaya mengenai budi pekerti. Bagi masyarakat Jawa, wewarah budi pekerti banyak diwarnai dari para pujangga seperti Ki Ageng Soerjomentaram dengan ajaran bahwa dalam menjalani hidup sebaiknya menghindari perilaku: ngangsa-angsa; ngaya-aya; golek benere dhewe (artinya; hidup harus selalu menunjukkan perilaku mulia atau terpuji). Raden Mas Sosrokartono (saudaranya Raden Ajeng Kartini) adalah sarjana sastra pertama dari Negeri Belanda mengajarkan sikap batin utama untuk menghadapi berbagai situasi konflik. Ajaran beliau adalah: sugih tanpo bandha; digdaya tanpo aji; nglurug tanpo bala; menang tanpo ngasorake (artinya: hidup sederhana).

Menurut Persyarikatan Muhammadiyah (Hadisaputra, 2010), di antara nilai-nilai keutamaan atau karakter yang perlu dimiliki bangsa Indonesia, baik secara individual maupun kolektif sebagai berikut. Pertama, nilai-nilai spiritualitas. Kedua, nilai-nilai solidaritas. 
Ketiga, nilai-nilai kedisiplinan. Keempat, nilai-nilai kemandirian. Kelima, nilainilai kemajuan dan keunggulan.

Berdasarkan uraian di atas, dapat dikatakan bahwa karakter bangsa adalah jati diri bangsa yang merupakan akumulasi dari karakter-karakter warga masyarakat suatu bangsa. Di dalam konsep karakter bangsa terkandung nilai-nilai luhur yang merupakan pedoman hidup untuk mencapai derajat kemanusiaan yang lebih tinggi, hidup yang lebih bermanfaat, kedamaian dan kebahagiaan.

Dalam konteks implementasi KTSP (kurikulum tingkat satuan pendidikan), sesungguhnya nilai-nilai tersebut dapat dimasukkan menjadi isi atau muatan kurikulum untuk memperkaya kajian materi pokok pembelajaran. Selanjutnya, nilai-nilai tersebut diintegrasikan ke dalam kegiatan pembelajaran setiap mata pelajaran yang berlaku di sekolah dalam rangka membentuk SDM berkarakter bangsa, sebagaimana yang dicita-citakan oleh para pendahulu kita (founding father). Hal ini selasar dengan salah satu prinsip implementasi KTSP, yaitu proses pembelajaran adalah membentuk kreasi lingkungan yang dapat membentuk atau mengubah struktur kognitif peserta didik, berhubungan dengan tipe pengetahuan yang harus dipelajari, dan harus melibatkan peran lingkungan sosial (Sanjaya, 2005: 81-82).

INTEGRASI NILAI-NILAI KAKAKTER BANGSA KE DALAM PEMBELAJARAN

Mengintegrasikan nilai-nilai yang terkandung dalam karakter bangsa ke dalam kegiatan pembelajaran, kita perlu terlebih dahulu menyepakati makna pembelajarn itu sendiri. Hal ini perlu dilakukan karena pemaknaan yang berbeda tentang konsep pembelajaran yang digunakan dapat berpengaruh terhadap kualitas integrasi nilai-nilai yang terkandung dalam karakter bangsa tersebut.

Mengacu pada pengertian bahwa pembelajaran merupakan bentuk implementasi kurikulum sebagai dokumen tertulis (Saylor, dkk, 1981:258), maka pembahasan tentang pembelajaran tidak bisa dipisahkan dari persoalan implementasi kurikulum yang berlaku. Pembelajaran merupakan wujud nyata dari implementasi kurikulum. Dengan pengertian yang demikian, kegiatan pembelajaran memiliki posisi yang sangat menentukan bagi keberhasilan kurikulum sebagai rencana tertulis.

Hasan (2002:1) mengatakan, "... jika kurikulum dalam bentuk rencana tertulis dilaksanakan, maka kurikulum dalam bentuk proses adalah realisasi atau implementasi dari kurikulum sebagai rencana tertulis". Bisa jadi, dua orang guru yang sama-sama mengimplementasikan sebuah kurikulum (misalnya, kurikulum mata pelajaran IPS) akan diterima atau dikuasai anak secara berbeda bukan karena isi atau aspek-aspek kurikulumnya yang berbeda, akan tetapi lebih disebabkan perbedaan dalam implementasi kurikulum yang diupayakan guru.

Begitu urgennya posisi kegiatan pembelajaran bagi terwujud atau tidaknya sebuah kurikulum, sangatlah tepat manakala persoalan pembelajaran merupakan persoalan esensial di kalangan 
pengembang dan pelaksana kurikulum. Terlebih lagi jika sistem pembelajaran yang ada lebih menekankan dimensi proses daripada hasil belajar. Oleh karena itu, agar kegiatan pembelajaran dapat terwujud secara optimal dan sesuai dengan kurikulum sebagai rencana tertulis, disarankan Hasan (2002:1) agar terlebih dahulu memahami secara tepat tentang filsafat dan teori yang digunakan.

Pada kesempatan lain, Hasan (2002: 2) memilah dua persoalan pokok dalam kegiatan pembelajaran, yaitu persoalan yang berhubungan dengan kenyataan kurikulum yang ada dan berlaku di sekolah, dan persoalan yang berhubungan dengan kemampuan guru untuk melaksanakannya. Khususnya yang berkaitan dengan persoalan kedua, ditegaskan oleh Sukmadinata (1988:218) dengan mengatakan bahwa pembelajaran hampir seluruhnya bergantung pada kreativitas, kecakapan, kesungguhan, dan ketekunan guru.

Bagaimana kaitannya dengan kegiatan pembelajaran untuk pembentukan SDM berkarakter bangsa? Mengacu pada asumsi bahwa pembelajaran merupakan bentuk konkret atau realisasi kurikulum sebagai dokumen tertulis di sekolah atau kelas, maka aktivitas pembelajaran yang relevan dilaksanakan guru untuk pembentukan SDM berkarakter bangsa tentu tidak bisa dilepaskan dari karakteristik kurikulum yang berlaku di sekolah, yaitu kurikulum tingkat satuan pendidikan (KTSP) dengan desain kurikulum berbasis kompetensi. Dengan demikian, apapun aktivitas pembelajaran yang diupayakan guru, aktivitas-aktivitas pembelajaran tersebut haruslah mampu memfasilitasi pembentukan dan pengembangan peserta didik berkarakter bangsa. Salah satu cara yang relevan diterapkan adalah pengintegrasian nilai-nilai yang terkandung dalam karakter bangsa ke dalam kegiatan pembelajaran setiap mata pelajaran yang tertera dalam kurikulum sekolah.

Pengintegrasian nilai-nilai karakter bangsa ke dalam kegiatan pembelajaran berarti memadukan, memasukkan, dan menerapkan nilai-nilai yang diyakini baik dan benar dalam rangka membentuk, mengembangkan, dan membina tabiat atau kepribadian peserta didik sesuai jatidiri bangsa tatkala kegiatan pembelajaran berlangsung. Nilai-nilai karakter bangsa, antara lain (1) cinta kepada Allah dan semesta beserta isinya; (2) tanggung jawab, disiplin dan mandiri; (3) jujur; (4) hormat dan santun; (5) kasih sayang, peduli, dan kerja sama; (6) percaya diri, kreatif, kerja keras dan pantang menyerah; (7) keadilan dan kepemimpinan, baik dan rendah hati; dan (9) toleransi, cinta damai dan persatuan. Oleh karena itu, integrasi nilai-nilai yang terkandung dalam karakter bangsa ke dalam kegiatan pembelajaran pada setiap mata pelajaran dalam konteks pembentukan karakter bangsa, sesungguhnya kegiatan tersebut ingin merealisasikan terhadap apa-apa yang tertera dalam kurikulum yang berlaku di sekolah, melalui kajian dan aplikasi nilainilai yang terkandung di dalam karakter bangsa pada kegiatan pembelajaran di sekolah.

Integrasi nilai-nilai karakter bangsa pada kegiatan pembelajaran dapat dilakukan melalui tahap-tahap perencana- 
an, implementasi, dan evaluasi. Ketiga tahapan pembelajaran tersebut diuraikan sebagai berikut.

\section{PERENCANAAN}

Integrasi nilai-nilai karakter bangsa memerlukan kegiatan perencanaan yang memadai, baik dalam bentuk perencanaan pelaksanaan pembelajaran maupun penataan lingkungan belajar. Perencanaan pembelajaran berkaitan dengan "apa dan bagaimana" pembelajaran dilaksanakan di dalam dan luar kelas. Produk dari kegiatan ini adalah rancangan pelaksanaan pembelajaran. Penataan lingkungan belajar bertujuan untuk mengatur berbagai situasi dan kondisi (fisik dan non fisik) yang dapat mengembangkan rasa kepekaan, fleksibilitas, demokratisasi, dan rasa tanggap peserta didik terhadap berbagai kebutuhannya.

\section{Penyusunan Rancangan Pelaksanaan Pembelajaran}

Rancangan pelaksanaan pembelajaran perlu dibuat guru sebagai acuan kegiatan atau pelaksanaan pembelajaran. Rancangan pelaksanaan pembelajaran dikembangkan berdasarkan atas silabus yang berlaku dan dikembangkan secara berkesinambungan.

Rancangan pelaksanaan pembelajaran memuat tahap-tahap kegiatan pembelajaran dari pertemuan ke pertemuan. Tahap-tahap kegiatan pembelajaran tersebut dikembangkan dengan tujuan memberi kesempatan kepada peserta didik belajar menguasai sejumlah kompetensi dengan tetap mengedepankan aktualisasi nilai-nilai karakter bangsa, baik di dalam maupun di luar kelas.

Cara menyusun rancangan pelaksanaan pembelajaran adalah (a) menulis identitas mata pelajaran; (b) menulis kompetensi dasar; (c) mengembangkan kegiatan pembelajaran dalam kolom yang tersedia yang memuat tahap-tahap pembelajaran, uraian kegiatan, metode pembelajaran, dan media serta sumber belajar yang digunakan guru; dan (d) sistem penilaian yang dipakai.

Rancangan integrasi nilai-nilai karakter bangsa disusun dengan terlebih dahulu mengkaji rumusan kompetensi yang akan dikuasai peserta didik. Para guru tatkala menyusun rancangan pembelajaran disarankan agar memahami terlebih dahulu nilai-nilai karakter bangsa yang terkait dengan rumusan kompetensi yang diharapkan dikuasai peserta didik. Selanjutnya, berdasarkan hasil identifikasi nilai-nilai karakter bangsa tersebut dikembangkanlah rancangan pelaksanaan pembelajaran sebagai acuan dalam melayani dan memfasisilitasi mereka dalam belajar.

\section{Pengaturan dan Penataan Lingkungan Belajar}

Integrasi nilai-nilai karakter bangsa ke dalam kegiatan pembelajaran di kelas memerlukan dukungan lingkungan belajar yang memadai. Lingkungan belajar yang memadai bagi keberhasilan integrasi nilai-nilai karakter bangsa ke dalam kegiatan pembelajaran memerlukan penataan dan pengaturan agar peserta didik mampu belajar sesuai dengan kebutuhan dan minatnya.

Beberapa kegiatan penataan dan pengaturan lingkungan belajar bagi ke- 
berhasilan integrasi nilai-nilai karakter bangsa ke dalam pembelajaran, antara lain (a) menyiapkan sarana pembelajaran yang dibutuhkan untuk integrasi nilai-nilai karakter bangsa ke dalam pembelajaran; (b) mengatur prasarana pembelajaran yang tersedia, dan (c) menatalingkungan(situasi dan kondisi) kelas bagi kepentingan menguasai kompetensi dan nilai-nilai karakter bangsa yang terkandung di dalamnya.

\section{PELAKSANAAN PEMBELAJARAN}

Tahap-tahap Pelaksanaan Pembelajaran

Integrasi nilai-nilai karakter bangsa ke dalam kegiatan pembelajaran dilaku- kan untuk semua mata pelajaran yang tersedia di kurikulum sekolah, yang diharapkan ada pada tahap pendahuluan, inti, dan penutup. Dengan demikian, pada setiap tahap pembelajaran akan diisi atau disertakan pesan-pesan moral atau nilai-nilai karakter bangsa yang relevan dengan materi pokok mata pelajaran yang sedang dibahas. Selanjutnya, agar diperoleh akurasi, ketepatan, dan kesesuaian antara nilai-nilai karakterbangsa yang akan dikembangkandengan materi pokoknya maka para guru dapat menggunakan bantuan tabel (baris - kolom) tentang skenario pembelajaran berikut.

\section{Tabel 1. Cara Mengintegrasikan Nilai-nilai Karakter Bangsa pada Tahap-tahap Pembelajaran}

\begin{tabular}{|c|c|c|c|c|}
\hline Tahap & Uraian Kegiatan & Materi Pokok & $\begin{array}{c}\text { Nilai-nilai } \\
\text { Karakter Bangsa }\end{array}$ & Waktu \\
\hline Pendahuluan & & & & $10 \%$ \\
\hline Inti & & & & $80 \%$ \\
\hline Penutup & & & & $10 \%$ \\
\hline
\end{tabular}

Dengan menggunakan bantuan tabel di atas, guru memiliki peluang secara cermat dan luas tentang kegiatankegiatan apa saja yang dilakukan guna menciptakan pembelajaran yang memfasilitasi peserta didik menguasai halhal yang terdapat dalam rumusan kompetensi dan nilai-nilai karakter bangsa yang terkandung di dalamnya.

Pembelajaran yang menekankan integrasi nilai-nilai karakter bangsa yang diharapkan adalah model pembelajaran yang memiliki ciri-ciri (1) menggunakan metode yang dapat mewujudkan rumusan kompetensi dan nilai-nilai karakter bangsa yang terkandung di dalam rumusan kompetensi dengan memberdayakan multipel inteligensi; (2) bersifat kontektual; (3) pembelajaran berlangsung secara interaktif, inspiratif, menyenangkan, memotivasi, menantang, dan dalam iklim yang kondusif; (4) berpusat pada siswa; (5) mengalokasikan waktu yang relevan dengan 
kebutuhan pemahaman kompetensi; (6) menggunakan berbagai setting pembelajaran untuk realisasi nilai-nilai karakter bangsa yang terkandung dalam rumusan kompetensi; dan (7) melaksanakan program remidial dan pengayaan sesuai dengan hasil kajian formatif.

\section{Pengelolaan Kelas}

Pengelolaan kelas merupakan bagian esensial dari kegiatan pembelajaran yang menekankan integrasi nilai-nilai karakter bangsa. Pengelolaan kelas bertujuan untuk menciptakan dan atau mempertahankan situasi dan kondisi belajar yang tetap memungkinkan peserta didik menguasai kompetensi, sekaligus mengamalkan nilai-nilai karakter bangsa.

Menciptakan kondisi belajar berarti menata kelas (fisik dan non fisik) yang memungkinkan peserta didik belajar secara memadai. Beberapa kegiatan yang dapat dilakukan, antara lain menata ruang kelas menurut kepentingan kegiatan belajar peserta didik, membuat aturan-aturan yang mengatur aktivitas belajar peserta didik menguasai kompetensi, memberi keteladanan latihan dan umpan balik, dan menciptakan kultur belajar yang di kalangan peserta didik.

Mempertahankan dinamika kelas merupakan proses kegiatan yang bertujuan agar aktivitas belajar tetap bernuansa pengamalan nilai-nilai moral. Bentuk-bentuk kegiatan mempertahankan dinamika kelas, antara lain mendisiplinkan peserta didik dalam belajar, menerapkan tata tertib sekolah secara konsekuen, dan menerapkan hukuman dan hadiah.

\section{Bimbingan Akademik}

Bimbingan akademik memiliki posisi strategis bagi keberhasilan peserta didik dalam integrasi nilai-nilai karakter bangsa. Bimbingan akademik merupakan bentuk layanan belajar yang dilakukan guru untuk membantu peserta didik yang dalam memecahkan masalah belajar. Di sini yang perlu ditegaskan adalah peserta didik perlu mendapat bimbingan akademik sesuai dengan keperluan belajarnya.

Beberapa kegiatan bimbingan belajar yang dapat dilakukan, antara lain; memberi program pengayaan dan remidi bagi peserta didik yang membutuhkan, bimbingan belajar bagi peserta didik yang mengalami masalah belajar secara khusus.

\section{PENILAIAN}

Tahap akhir dari kegiatan integrasi nilai-nilai karakter bangsa dalam kegiatan pembelajaran adalah melakukan penilaian. Penilaian dapat dilakukan untuk mengetahui keberhasilan peserta didik dalam menyelesaikan tugas-tugas belajar, yang dilakukan pada saat proses maupun akhir pembelajaran.

Komponen untuk menentukan nilai akhir, antara lain kehadiran dalam tatap muka, keberhasilan dalam menyelesaikan tugas-tugas belajar, nilai ujian tengah semester, dan nilai akhir semester. Kesemuanya komponen tersebut kemudian dikemas dalam bentuk laporan hasil belajar peserta didik yang diberikan kepada orang tua setiap akhir semester. Bentuk laporan hasil belajar dapat berupa rekap nilai yang telah di- 
capai peserta didik atau dalam bentuk laporan nilai.

\section{IMPLIKASI}

Apa implikasi penerapan pembelajaran yang mengintegrasikan nilai-nilai karakter bangsa bagi sekolah, guru, peserta didik, dan orang tua? Untuk menjawab pertanyaan ini terlebih dahulu perlu diketahui dan dipahami kedudukan dan peran ketiga pihak tersebut dalam konteks penyelenggaraan pembelajaran yang mengintegrasikan nilai-nilai karakter bangsa pada semua mata pelajaran. Bertitik tolak dari kedudukan dan peran masing-masing pihak tersebut kemudian dirumuskan tentang apa yang sebaiknya mereka upayakan sehingga pelaksanaan pembelajaran tersebut dapat berlangsung dan berhasil secara optimal.

Apabila dilihat dari tingkatan penyelenggaraan pendidikan, sekolah merupakan institusi yang berada pada tingkatan terbawah yaitu sebagai tempat berlangsungnya proses transmisi dan transformasi pengalaman belajar kepada peserta didik. Dengan kedudukannya yang demikian, tidaklah berlebihan manakala sekolah dikatakan sebagai institusi esensial bagi keberlangsungan dan keberhasilan programprogram yang telah terumuskan dalam rencana strategi sekolah, apalagi dengan diterapkannya pendekatan school based management.

Setidaknya, pihak sekolah memiliki kewenangan dan otorita yang lebih mandiri dalam menjabarkan dan mengembangkan apa yang terumuskan dalam program sekolah, menentukan strategi implementasi, dan alokasi waktu yang sesuai dengan kondisi dan kebutuhan setempat. Sekolah bukan sekadar berperan sebagai pelaksana, akan tetapi berperanan pula sebagai pengembang model pembelajaran yang menekankan integrasi nilai-nilai karakter bangsa sesuai dengan kondisi dan kebutuhan setempat.

Implikasi yang bisa dikemukakan sehubungan dengan kedudukan dan peran sekolah di atas, serta ingin tetap eksis dan berperan sebagai pihak terdepan dalam pengembangan model pembelajaran tersebut secara efektif dan adaptabel maka sekolah dituntut (1) proaktif mencari informasi tentang berbagai nilai-nilai karakter bangsa yang terjadi di masyarakat dengan memperhatikan masukan-masukan dari segenap stakeholder dalam rangka pemutakhiran program pendidikan, sebagaimana dikatakan Joyce, B dan Weils, M. (2004) bahwa "As society changes and knowledge abaout curriculum and instruction increases, schools need to assimilate and accommodate many new realities"; (2) mampu mengubah etos kerja dan kultur akademik warga sekolah. Etos kerja yang tinggi dan kultur akademik yang baik perlu dimiliki para warga sekolah jika mengharapkan keberlangsungan dan kesuksesan integrasi nilai-nilai karakter bangsa pada kegiatan pembelajaran di sekolah; dan (3) menyediakan berbagai fasilitas belajar yang mendukung bagi integrasi nilainilai karakter bangsa pada kegiatan pembelajaran, misalnya ruang belajar, buku pelajaran, perpustakaan, dan laboratorium sains dan komputer. 
Guru merupakan pihak terdepan dalam kegiatan pembelajaran berbasis nilai-nilai karakter bangsa. Untuk mendukung optimalisasi peran guru dalam integrasi nilai-nilai karakter bangsa ke dalam kegiatan pembelajaran, mereka hendaknya memiliki wawasan pengetahuan dan pengalaman tentang nilainilai yang terkandung dalam karakter bangsa secara luas dan memadai yang berkembang di masyarakat Indonesia.

Di samping itu, para guru hendaknya menyadari peran mereka sebagai teladan bagi peserta didiknya. Dengan demikian, tutur kata, pola pikir, perilaku, dan cara-cara berpakaian mereka hendaknya dapat menjadi contoh dan teladan bagi anak-anaknya. Keteladan merupakan kunci sukses bagi integrasi nilai-nilai karakter bangsa ke dalam kegiatan pembelajaran di sekolah.

Peserta didik merupakan pihak yang akan menerima dan memperoleh seperangkatkemampuan yang dirumuskan dalam model pembelajaran tersebut. Dalam hal ini, peserta didik perlu diposisikan sebagai subjek dari model pembelajaran yang menekankan integrasi nilai-nilai karakter bangsa. Program-program pendidikan di sekolah bukan semata-mata diperuntukkan bagi guru, akan tetapi lebih diperuntukkan bagi peserta didik.

Dengan posisi yang demikian maka sepantasnya apabila mereka dilibatkan dalam mengembangkan program-program pembelajaran yang mendukung integrasi nilai-nilai karakter bangsa. Saylor dan kawan-kawan (1981) mengatakan, "As a member of the learner population, they also have opportunities re- lated to their level of maturaty to help in planning the total program; in this process of curriculum planning they participate but not necessarily have lead". Oleh karena itu, prinsip-prinsip student centered, peserta didik aktif, dan ketrampilan proses perlu diperhatikan dalam model pembelajaran tersebut.

Implikasinya adalah peserta didik dituntut ikut berpartisipasi secara aktif dalam menjabarkan, mengembangkan, dan mengimplementasikan nilai-nilai moral yang terkadung di dalam rumusan kompetensi bagi terbentuknya suatu profil lulusan sebagaimana yang dirumuskan dalam kompetensi yang bersumber dari visi dan misi sekolah. Hal ini berarti bahwa setiap peserta didik dituntut memiliki kemampuan-kemampuan (1) kreatif dan inovatif dalam belajar; (2) menciptakan suasana kompetitif dalam belajar; (3) menghargai dan menghormati setiap warga sekolah; (4) mengikuti berbagai perubahan dan perkembangan ipteks yang sedang terjadi di masyarakat, untuk selanjutnya dibawa ke sekolah sebagai bahan masukan bagi peningkatan kualitas sekolah; dan (5) memiliki sense of belongingness terhadap berbagai program sekolah.

Orang tua dapat dikatakan sebagai salah satu pihak yang ikut bertanggungjawab bagi kesuksesan programprogram sekolah. Artinya, keberhasilan sekolah sangat ditentukan seberapa jauh tingkat partisipasi orang tua terhadap implementasi program-program yang diselenggarakan sekolah. Ada korelasi antara kemajuan dan kualitas sekolah dengan tingkat kesadaran orang tua terhadap pendidikan anaknya. 
Implikasinya, orangtua dituntut berpartisipasi aktif dalam merancang dan mengembangkan nilai-nilai moral yang diyakini perlu diberikan peserta didik. Hal ini berarti bahwa pihak orang tua perlu (1) meningkatkan kesadaran terhadap arti penting nilai-nilai karakter bangsa bagi anaknya; (2) menyediakan berbagai fasilitas belajar yang diperlukan anaknya untuk tumbuh kembangnya nilai-nilai karakter bangsa dalam diri anak-anak; dan (3) melakukan kerja sama secara sinergis dengan pihak sekolah guna memikirkan dan mencari solusi terhadap berbagai problem yang dialami sekolah, terutama yang berkaitan dengan demoralisasi anak didik.

\section{PENUTUP}

Di akhir tulisan ini, penulis ingin kembali menegaskan bahwa integrasi nilai-nilai karakter bangsa dapat dilakukan pada kegiatan pembelajaran semua mata pelajaran di sekolah untuk menyiapkan lulusan menguasai kompetensi dan sekaligus mengaplikasikan nilai-nilai karakter bangsa pada kehidupan sehari-hari. Dalam konteks implementasi KTSP, cara ini relevan dilakukan guru yang berkeinginan menyiapkan lulusan kompeten di bidangnya, sekaligus berkarakter bangsa.

Integrasi nilai-nilai karakter bangsa dalam kegiatan pembelajaran dapat dilakukan pada tahap-tahap; pendahuluan, inti, dan penutup. Di sini, yang perlu diperhatikan adalah setiap tahap pembelajaran perlu ada porsi waktu untuk aktualisasi nilai-nilai karakter bangsa sebagaimana yang terkandung dalam rumusan kompetensi. Oleh kare- na itu, merupakan suatu keharusan bagi pihak sekolah, guru, orang tua, dan peserta untuk mewujudkan kegiatan pembelajaran yang di dalamnya terkandung nilai-nilai karakter bangsa dengan harapan supaya lulusan sekolah benarbenar menguasai kompetensi sekaligus melaksanakan tindakan-tindakan yang merupakan pengejawantahan dari nilainilai karakter bangsa, sebagaimana yang dikehendaki masyarakat.

\section{UCAPAN TERIMA KASIH}

Pada kesempatan ini perkenankan saya menyampaikan terima kasih kepada Bapak Prof. Dr. Burhan Nurgiyantoro selaku Ketua LPM Universitas Negeri Yogyakarta berserta staf yang telah menerbitkan tulisan saya. Di samping itu, kepada Bapak Prof. Pardjono, Ph.D. yang telah bersedia mereview tulisan saya menjadi lebih baik, dari sisi substansi dan cara pemaparannya. Semoga Allah SWT memberkahi kepada semua pihak yang telah membantu saya dalam penulisan ini.

\section{DAFTAR PUSTAKA}

Chrisiana, Wanda. 2005. “Upaya Penerapan Pendidikan Karakter bagi Mahasiswa: Studi Kasus di Jurusan Teknik Industry UK Petra". Jurnal Teknik Industri, Vol. 7. No. I. Juni 2005. Surabaya: Universitas Kristen Petra.

Ekowarni, Endang. 2010. Pengembangan Nilai-nilai Luhur Budi Pekerti sebagai Karakter Bangsa. http:/be- 
lanegarari.wordpress.com/2009/-

08/25/. Diunduh pada tanggal tanggal 26 Maret 2010.

Hadisaputra. 2009. "Revitalisasi Karakter Bangsa". Tribun Timur, 18 Juni 2009.

Hasan, Said Hamid. 2002. "Kurikulum Berbasis Kompetensi Berdasarkan SK Mendiknas 232/2000 dan Alternatif Pemecahannya". Makalah Seminar Nasional, tanggal 11 Mei 2002 di UNY.

Joyce, B \& Weils, M. 2004. Models of Teaching. (Seventh Edition). Boston: Pearson Education, Inc.

Kedaulatan Rakyat, 25 April 2007.

Kompas, 26 April 2007.

Kompas, 26 Maret 2010.

Sanjaya, Wina. 2005. Pembelajaran dalam Implementasi Kurikulum Berbasis Kompetensi. Jakarta: Prenada Media.

Saylor J.G. dan kawan-kawan. 1981. Curriculum Planning for Better Teaching and Learning. Fourth Edition. Japan: Holt, Rinehart and Winston.

Syaodih S. Nana. 1988. Prinsip dan Landasan Pengembangan Kurikulum. Jakarta: P2LPTK Ditjen Dikti Depdiknas. 